\title{
The Transition to Junior High School: Beliefs of Pre- and Posttransition Teachers
}

\author{
Carol Midgley, ${ }^{1}$ Harriet Feldlaufer, $^{2}$ and Jacquelynne S. Eccles ${ }^{3}$
}

Received October 15, 1987; accepted March 18, 1988

The beliefs of 107 teachers who students have for mathematics the last year of elementary school are compared to the beliefs of 64 teachers the same students have for mathematics the first year of junior high school. As hypothesized, posttransition teachers trust students less, believe more strongly in controlling and disciplining students, and have a weaker sense of teaching efficacy than do pretransition teachers. There are no significant differences in beliefs about the nature of ability as a fixed trait. It is suggested that societal stereotypes about early adolescents may flourish in school settings that are exclusively for that age group, so that teachers believe these students are unlikely to make much academic progress and must be controlled.

This research was made possible by grants from the National Institute of Mental Health (MH31724) to Jacquelynne S. Eccles, the National Institute of Child Health and Human Development (HD17296) to Jacquelynne S. Eccles, and the National Science Foundation (BNS-8510504) to Jacquelynne S. Eccles and Allan Wigfield.

'Research Associate, Institute for Social Research, Ann Arbor, Michigan 48106. Received Ph.D. in Education from the University of Michigan. Research interests are adolescent development, middle years education, teacher beliefs, and classroom processes. To whom correspondence should be addressed.

${ }^{2}$ Associate Education Consultant, Connecticut State Department of Education, Hartford, Connecticut 06145 . Received M.A. in Education from the University of Michigan. Research interests are adolescent development, classroom environments, and supporting beginning teachers. ${ }^{3}$ Professor, Department of Psychology, University of Michigan, Ann Arbor, Michigan 48109. Received Ph.D. in Psychology from the University of California at Los Angeles. Research interests are development of self-concept, subjective task value, interests, and activity preferences, especially during early and middle adolescence. Also investigating the impact of school and family experiences on these constructs.

543 


\section{INTRODUCTION}

For a number of years educators and psychologists have expressed concern about the deterioration of students' achievement-related attitudes, values, and performance after the transition to junior high school, and have speculated about the reasons for these negative shifts (e.g., Eccles et al., 1984; Finger and Silverman, 1966; Hawkins and Berndt, 1985; Lipsitz, 1977; 1980; Mergendoller, 1982; Silberman, 1970; Simmons et al., 1979; Sprintall, 1985; Ward et al., 1982). Simmons, Blyth, and their colleagues advance a "developmental preparedness" hypothesis based on the belief that the timing of the transition to junior high school results in more disruption to the individual than would a similar transition a few years later "after the individual has developed a more mature sense of who he or she is" (Blyth et al., 1983, p. 106). Recent investigations of the effect of the timing of the transition have not, however, provided a consistent picture (Nottelmann, 1987; Petersen et al., 1987). We have argued that the nature of the transition, as well as the timing, must be examined, and have suggested that differences in the classroom environment before and after the transition to junior high school may contribute to a decline in achievement motivation for some children (Eccles and Midgley, in press; Eccles et al., 1984; Feldlaufer and Midgley, 1987).

Teachers are a very important part of the classroom environment. A long history of work on teacher effectiveness has documented how teacher expectancies and beliefs influence student motivation and achievement both directly through observable teacher behaviors and indirectly through more subtle forms of communication (Brophy and Good, 1974; Duncan and Biddle, 1974; Dusek, 1985; Good, 1981). If the beliefs of those who teach students after the transition to junior high school are less positive and facilitative than the beliefs of those who teach students before the transition, a decline in student motivation and performance may result. Two teacher belief systems seem especially relevant: teacher beliefs about trusting, disciplining, and controlling students; and teacher beliefs about both their personal effectiveness in influencing student performance and the general modifiability of ability. Both of these belief systems have been linked to student motivation and performance, and both are likely to vary across the junior high school transition. For example, a controlling or mistrustful teacher orientation, as compared to an orientation that values student autonomy and is based on trust, is associated with higher levels of teacher/pupil conflict (Brooks, 1977); more intense feelings by students of isolation, alienation, powerlessness, normlessness, and hostility toward school (Hoy, 1972; Rafalides and Hoy, 1971; Waple, 1974); and lower levels of student intrinsic motivation and perceived competence (Deci et al., 1981; Green and Foster, 1986). Although the relation between teacher sense of personal effectiveness or efficacy and student achievement-related beliefs is yet to be investigated, a positive relation with 
student achievement has been found, suggesting that teacher efficacy does influence students (Armor et al., 1976; Ashton et al., 1983; Berman et al., 1977). Given these associations, it seems likely that differences in these teacher beliefs before and after the transition to junior high school could influence student motivation. As a first step in assessing this hypothesis, we need to determine whether sixth-grade elementary school (pretransition) teachers have different beliefs than seventh-grade junior high school (posttransition) teachers.

Several characteristics of the junior high school make it probable that junior high school teachers will hold different beliefs than elementary school teachers. Junior high schools are typically larger and less personal than elementary schools (Simmons and Blyth, 1987). Junior high school teachers are often subject matter specialists and they typically instruct a much larger number of students than do elementary teachers in self-contained classrooms, making it less likely that they will come to know their students well, to feel they are trustworthy, and to grant them autonomy. Junior high school teachers may feel it is difficult to affect the achievement af a large number of students, especially since they see them for a relatively small proportion of the school day. In addition, feelings of trust and efficacy may be difficult to sustain in large, impersonal, bureaucratic organizations and rigid authority structures may develop (Anderson, 1968; Lawler, 1976; Porter and Lawler, 1965).

Finally, assigning students to classes on the basis of their ability, particularly in mathematics, becomes much more frequent after the transition to junior high school (Oakes, 1981). Once students have been assigned to a classroom on the basis of their ability, mobility to another ability level is infrequent (Metz, 1978; Oakes, 1981). This practice, coupled with increasing pressure to grade children on relative performance rather than on improvement or mastery, may engender a belief in junior high school teachers that differences in student ability are stable and that teacher influences on student achievement are relatively minor.

Because of these organizational differences, we predict that seventhgrade junior high school teachers will trust their students less, will believe more strongly in controlling and disciplining students, will feel less personally efficacious, and will see students' ability as more fixed than do sixth-grade elementary school teachers. Existing empirical data relevant to these predictions are summarized below.

\section{Teachers' Beliefs About Trusting and Controlling Students}

Twenty years ago Willower and Jones (1967) conducted a 14-month field study in one junior high school and concluded that preoccupation with 
student control permeated the life of the school. Since that time Willower and others have made substantial theoretical and empirical contributions to an understanding of the determinants and consequences of educators' beliefs about controlling students (e.g., Willower, 1977; Willower et al., 1973). In most of these studies trust and control are not differentiated but rather are considered components of a general pupil control ideology. ${ }^{4}$

A number of studies have investigated possible determinants of variation in educators' beliefs about controlling students. The determinant of particular relevance to our study is school level. In support of our prediction, educators in secondary schools have a stronger orientation to control than elementary school educators (Barfield and Burlingame, 1974; Brenneman et al., 1975; Hoy, 1968; Jury et al., 1975; Leppert and Hoy, 1972; Williams, 1972; Willower et al., 1973; Willower and Jones, 1967; Willower and Landis, 1970; Willower and Lawrence, 1979; Yuskiewicz and Willower, 1973). None of these studies, however, looked at the transition from elementary school to junior high school.

A controlling ideology is also related to teacher sex, with males endorsing control more than females (Brenneman et al., 1975; Brooks, 1977; Budzik, 1971; Hedberg, 1973; Helsel, 1971a; Jones, 1969; Jury et al., 1975; McArthur, 1978; McBride, 1972; Williams, 1972), and to teaching experience, with more experienced teachers expressing a stronger belief in control and discipline than student teachers or less experienced teachers (Brenneman et al., 1975; Budzik, 1971; Hamil, 1971; Hedberg, 1973; Helsel, 1971a, b; Hoy, 1967, 1968, 1969; Jury et al., 1975; Leppert and Hoy, 1972; McArthur, 1978; McBride, 1972; Roberts and Blankenship, 1970; Williams, 1972; Willower and Landis, 1970; Yuskiewicz and Willower, 1973). Since teacher sex and experience may covary with grade level taught, we have controlled for these characteristics in assessing grade level effects.

\section{Teachers' Beliefs About Personal Teaching Efficacy and the Nature of the Ability to Learn}

Although the conceptualization and measurement of teachers' sense of efficacy is relatively recent, research involving related constructs, such as teacher locus of control, attributions, and expectancies, has a longer history (e.g., Brookover et al., 1979; Brophy and Evertson, 1977; Cooper and Baron, 1977; deCharms, 1976; Medway and Baron, 1977; Murray and Stae-

\footnotetext{
${ }^{4}$ Very little systematic research has been conducted on trust in educational institutions. Recently an attempt was made to develop and test a set of measures to assess trust in the public schools (Hoy and Kupersmith, 1984). These measures assess faculty trust of their principal, each other, and their school district. Teacher trust of their students is not included.
} 
bler, 1974; Rutter et al., 1979). A distinction is usually made between personal teaching efficacy and general teaching efficacy. Personal teaching efficacy is a belief in one's personal ability to affect student learning; for example, "If I try really hard, I can get through to even the most difficult or unmotivated students." General teaching efficacy is a belief that student learning can be influenced by effective teachers; for example, "When it comes right down to it, a teacher really can't do much because most of a student's motivation and performance depends on his or her home environment." It has been suggested that general teaching efficacy has much in common with teacher beliefs about the nature of ability as either highly stable, or malleable and expanding, and about the capacity of some groups of children to learn (Ashton and Webb, 1986; Bloom, 1978; Brookover et al., 1979; Eccles and Wigfield, 1985; Marshall and Weinstein, 1984).

The Rand Corporation conducted the first studies measuring teacher efficacy 12 years ago. For two school evaluation studies, they developed the two items cited above and used their total score as a measure of teacher efficacy, finding a strong positive relationship with gains in reading achievement (Armor et al., 1976) and successful implementation of curriculum innovation (Berman et al., 1977). Since then a number of investigators have looked at the effects of teaching efficacy using these two items as a composite (e.g., Ashton et al., 1983; Fuller and Izu, 1986; Glickman and Tamashiro, 1982; Guskey, 1981a; Passe, 1984), although there is evidence that they represent separable constructs with different determinants and consequences (Ashton et al., 1982; Gibson and Dembo, 1984; Guskey, 1981a, 1982, 1986; Rose and Medway, 1981; Selove, 1984).

Although there has been much speculation about the determinants of teachers' sense of efficacy, there have been few systematic empirical investigations, and the results are inconsistent, particularly with regard to grade level effects. For example, although there was no relation between efficacy beliefs and grade level in studies conducted by Trentham, Silvern, and Brogdon (1985) and Guskey (1981b, 1986), Fuller and Izu (1986) reported that elementary school teachers feel more efficacious than secondary school teachers. Similarly, in one study elementary school teachers accepted greater responsibility for their lack of success with students than did secondary teachers (Guskey, 1981a). None of these studies, however, looked at the elementary to junior high school contrast of interest to us. Consequently, although there is good theoretical justification for predicting that seventhgrade junior high school teachers will feel less efficacious and will see student ability as more fixed than sixth-grade elementary school teachers, there is virtually no empirical data available to test these hypotheses.

Other teacher characteristics have yielded a mixed picture of influences. Teacher sex appears unrelated to sense of efficacy (Beady and Hansell, 1981; 
Showers, 1980; Trentham et al., 1985), although Guskey (1981a) found that female teachers assume greater responsibility for positive learning outcomes than do male teachers, but not for negative learning outcomes. The findings are mixed regarding the relation between teaching experience and efficacy beliefs (Ashton et al., 1983; Beady and Hansell, 1981; Berman et al., 1977; Brown and Gibson, 1982; Glickman and Tamashiro, 1982; Guskey, 1981b; Showers, 1980). But given that these characteristics may be important, we have controlled for their effects in assessing our predicted grade level effects.

The research reported here represents the first comprehensive comparison of the beliefs of pre- and posttransition teachers. In addition, this study expands on existing methodological work by making a distinction between teacher beliefs about trusting and controlling students, as well as between teacher beliefs about personal teaching efficacy and the modifiability of ability. Of particular importance, this study compares the beliefs of teachers in different school organizations (elementary and junior high) who have the same students within a two-year period. In this way differences in the characteristics of the students to whom teachers are exposed are minimized, and the effect of differences in the school organization can be interpreted more easily than in studies conducted at a single time point. We make the following hypotheses:

1. Posttransition teachers are more oriented to controlling and disciplining students than are pretransition teachers.

2. Posttransition teachers trust students less than do pretransition teachers.

3. Posttransition teachers have a weaker sense of personal teaching efficacy than do pretransition teachers.

4. Posttransition teachers believe ability is a fixed trait rather than a modifiable state more than do pretransition teachers.

\section{METHOD}

\section{Sample}

The data used for this study were collected as part of a two-year, fourwave longitudinal study (the Transitions in Early Adolescence Project) investigating the impact of changes in the classroom and family environment on early adolescents' self-perceptions and achievement-related motives, beliefs, values, and behaviors. Twelve school districts located in middle-income communities in southeastern Michigan were included in the study. These communities are within a 50-mile radius of Detroit and many residents work in 
automobile-related industries. An effort was made to include districts that varied in their ability grouping and evaluation practices. All teachers in those districts who taught mathematics to fifth or sixth graders scheduled to make a transition to middle or junior high school were recruited for the Transition Project. All participation was voluntary; $95 \%$ of the eligible teachers in the participating schools agreed to join the study.

The data from a subset of the sample were selected for this study. ${ }^{5}$ The sample includes 107 sixth-grade elementary school (pretransition) teachers and 64 seventh-grade junior high school (posttransition) teachers. There are fewer post- than pretransition teachers because, at the junior high school level, each teacher instructs several sections of mathematics. All the junior high schools in this study use a traditional departmentalized organization.

\section{Measures}

Drawing from the work of Ashton and Webb (1982, 1986), Brookover and his colleagues (1979), and Willower and his colleagues (1973), we developed a teacher questionnaire assessing a wide range of beliefs including trust and respect for students, beliefs about the need to control and discipline students, feelings of personal teaching efficacy, and views of ability as a modifiable intellectual skill or a stable trait. Each question uses a 5-point Likert-type scale ranging from (1) Strongly Disagree to (5) Strongly Agree. Through extensive pilot testing in upper elementary and junior high school mathematics classrooms, items were identified that teachers tended to leave unanswered or that had low variance or were highly skewed. These items were either deleted or reworded.

In order to show empirical support for the differentiation of the constructs of interest, a principal components analysis was undertaken. Based on Cattell's scree test of the characteristic roots, a common factor analysis was performed and four factors were extracted. Orthogonal and oblique rotations were used to interpret the pattern of loadings, and in both cases the factors were theoretically distinct and represented the four constructs under investigation: teacher beliefs about trusting students (Trust), the need to discipline and control students (Control), personal teaching efficacy (Efficacy), and ability as a modifiable state or stable trait (Fixed Ability). Composites were created by summing the item scores. Table I illustrates the wording of items included in the composites. Cronbach's alpha reliability coefficients

\footnotetext{
'In two school districts policy changed during the course of data collection so that some students did not move to a new school. Teachers of students who did not make a school transition between years one and two were excluded from this study. In addition, one pretransition teacher and four posttransition teachers failed to return a teacher questionnaire.
} 


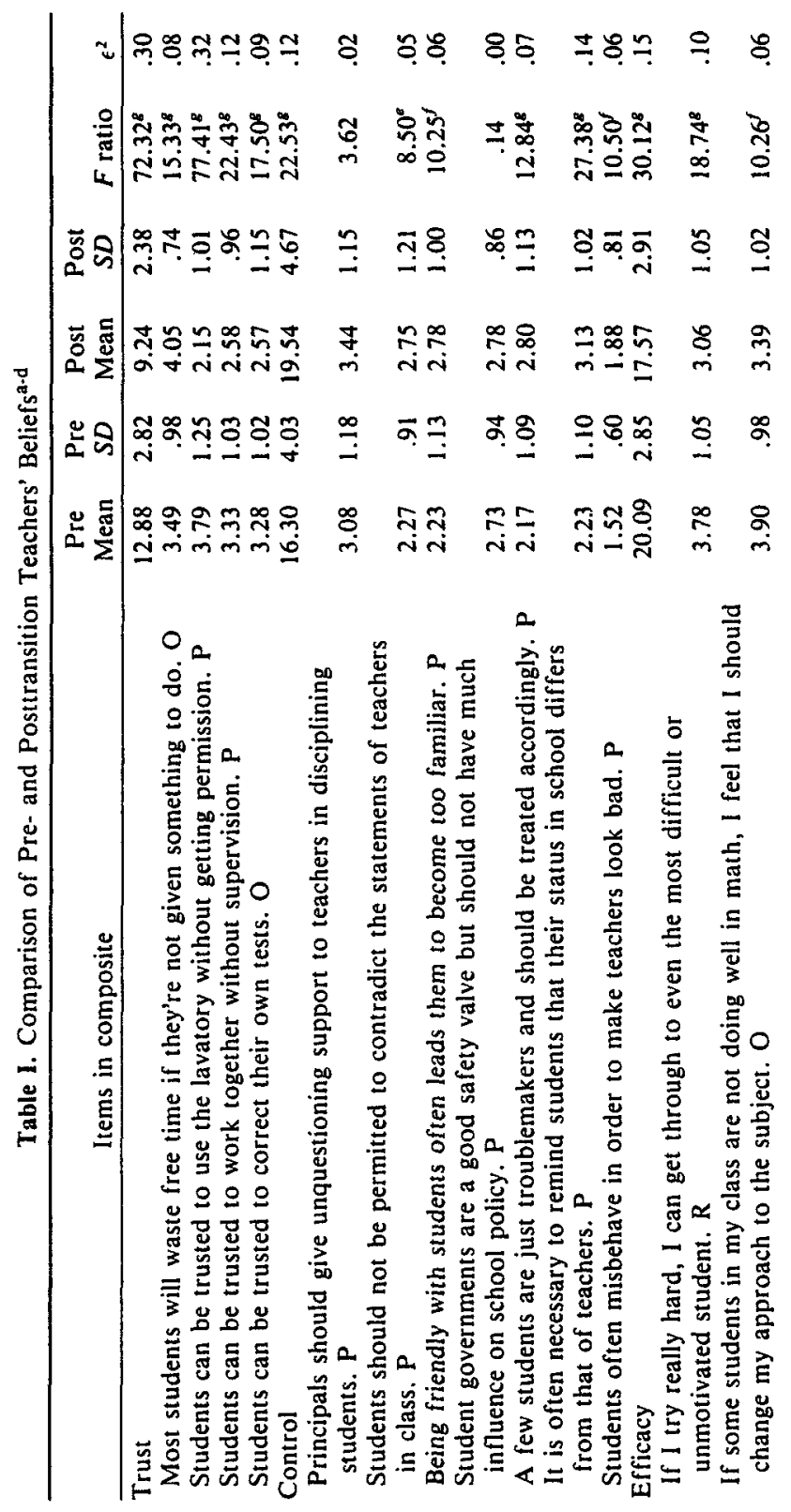




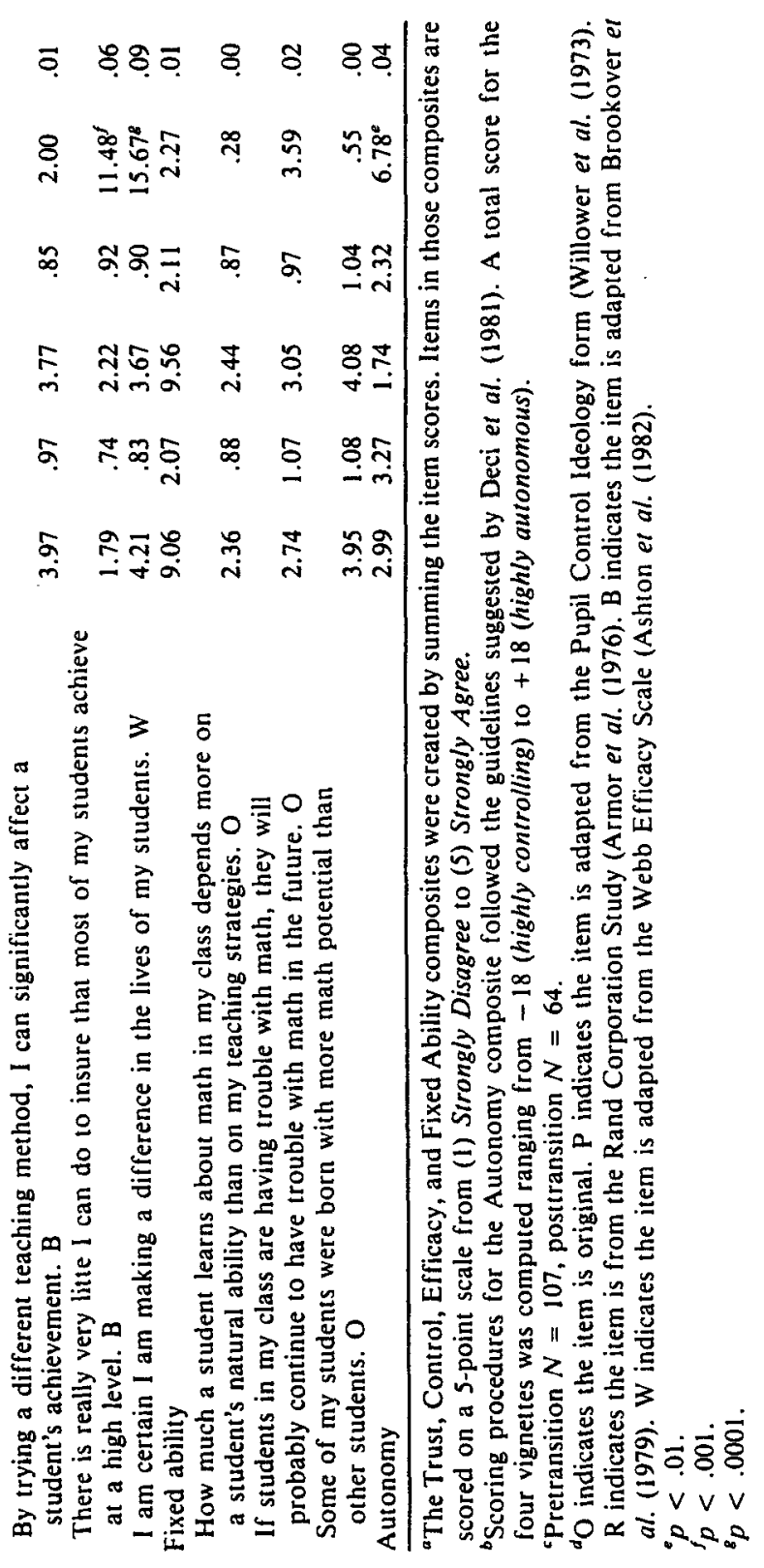


were computed for each composite and are as follows: Trust .63 , Control .72 , Efficacy .65, and Fixed Ability $.50 .^{6}$

The teacher questionnaire also includes 16 questions based on four vignettes developed by Deci and his colleagues to assess adults' orientations toward control vs. autonomy in their interactions with children (Deci et al., 1981). These vignettes describe typical kinds of problems that occur in schools. For each vignette, teachers are asked to rate the appropriateness, on a scale of 1-7, of each of four alternative ways of dealing with the problem. Responses are suggested ranging from highly controlling (the teacher decides on the solution and uses sanctions to ensure that it is implemented) to highly autonomous (the teacher encourages the child to think about the problem and arrive at a solution). For the four vignettes, a total score was computed for each teacher on a continuum from highly controlling to highly autonomous (Autonomy), as suggested by Deci et al. (1981). ${ }^{7}$

Finally, teachers were asked how long they had been teaching math at the current grade level, how adequate their math training had been, and how much formal math training they had beyond the minimum required for certification. In addition, posttransition teachers were asked if they had elementary certification, secondary certification, or both, since in the state of Michigan either elementary or secondary certification allows one to teach mathematics at the seventh-grade level.

\section{Procedure}

Analyses reported here are based on data collected via a teacher questionnaire given to pretransition teachers in the fall of 1983 and posttransition teachers in the fall of 1984 . Teachers were asked to return their completed questionnaires in a mailer provided by the researchers.

\footnotetext{
'In order to compare the beliefs of pre- and posttransition teachers, the same scales must be used with each group. For this reason the factor analysis was conducted with item scores for the entire teacher sample. If the items had been factored separately for elementary and junior high school teachers, the factors and resulting scales would have differed somewhat for the two samples and in all likelihood the alpha coefficients would be higher. The factor analysis is based on item correlations, and we know that the correlations among the items and among the composites are somewhat different for the two samples. In order to use the same scales for both samples, some error is introduced, and thus the alpha coefficients are not optimal. However, in a study such as this, the scales are being used to compare mean differences in scores on the same items and scales, and alpha is less important than it would be in a study using scales to predict outcomes. Table I shows the differences between pre- and posttransition teachers at both the scale and item level.

'For a complete description of the development and validation of this instrument, see Deci et al. (1981).
} 


\section{RESULTS}

\section{Relations Among Beliefs}

Table II contains the intercorrelations among the beliefs composites for both the pre- and posttransition samples. These correlations are low to moderate for both samples, indicating that these scales tap distinct dimensions of teachers' belief systems. Again, as in the factor analyses, we find empirical support for differentiating trust and control, as well as for distinguishing personal teaching efficacy from a general belief about the modifiability of ability. As one would expect, the two autonomy/control composites (Control and Autonomy) are moderately correlated both years. Some of the patterns of relations change from year one to year two. For pretransition teachers, Control, Autonomy, Trust, and beliefs about personal teaching efficacy (Efficacy) are related. Believing one is an efficacious teacher is associated with trusting students, holding more humanistic views about controlling and disciplining students, and endorsing strategies that provide informational more than controlling feedback to students. For pretransition teachers, Fixed Ability is only weakly related to the other beliefs. For posttransition teachers, Control and Autonomy are not significantly correlated with Efficacy or Trust. In addition, Fixed Ability is moderately correlated with both Control and Efficacy.

\section{Comparison of Pre- and Posttransition Teachers' Beliefs}

Using analysis of variance to test for differences between pre- and posttransition teachers, highly significant year effects were found for four of the five composites. As predicted, posttransition teachers trust students less, are

Table II. Intercorrelations for Composite Measures of Teachers' Beliefs ${ }^{p}$

\begin{tabular}{lrrrrr}
\hline & \multicolumn{5}{c}{ Intercorrelations among composites } \\
\cline { 2 - 6 } Composite & I & \multicolumn{1}{c}{ II } & III & IV & \multicolumn{1}{c}{ V } \\
\hline I. Trust & & $-.34^{b}$ & $.30^{b}$ & -.06 & .20 \\
II. Control & -.23 & & $-.33^{b}$ & .03 & $-.28^{b}$ \\
III. Efficacy & .03 & -.21 & & -.15 & $.31^{b}$ \\
IV. Fixed Ability & -.07 & $.33^{b}$ & $-.41^{b}$ & & -.15 \\
V. Autonomy & .16 & $-.41^{b}$ & .16 & -.08 & \\
\hline
\end{tabular}

${ }^{a}$ Correlations among the composites for the year one sample $(N=$ 94) are shown above the main diagonal; correlations among the composites for the year two sample $(N=59)$ are shown below the main diagonal.

${ }^{b} p<.01$. 
more controlling in their attitudes toward students (on both scales measuring control/autonomy), and feel less personally efficacious than do pretransition teachers. There was no significant difference in beliefs about the modifiability of ability, although the trend was in the predicted direction (See Table I).

Consistent with past research, there was also a sex difference on the two scales measuring control/autonomy, with male teachers more oriented to controlling students than female teachers (Autonomy $F[1,156]=6.61$; $p<.01$; Control $F[1,164]=7.63 ; p<.01$ ). Willower, Hoy, and their colleagues consistently find that secondary teachers have a more controlling ideology than elementary teachers, and male teachers have a more controlling ideology than female teachers, but note that the ratio of male to female teachers at the elementary and secondary levels differs; thus grade level and sex of teacher may be confounded. Using multiple regression to partial out the effects of sex of teacher, the highly significant differences between the pre- and postransition teachers in orientation to control remain (Autonomy $t[2,155]=2.38, p=.0184$; Control $t[2,163]=-4.69 ; p<.0001$ ). No interaction effects of grade level and teacher sex were found. Sex differences were not found on the other beliefs composites.

Using analysis of variance to test for differences between pre- and posttransition teachers' experience and training in math, pretransition teachers have taught math "at this grade level" longer than posttransition teachers $(F[1,169]=5.23 ; p<.03)$. In addition, pretransition teachers more than posttransition teachers feel that their math training to teach "at this grade level" is adequate $(F[1,169]=15.54 ; p<.0001)$. There were no differences in the amount of training beyond the minimum required for certification.

Given the relation between teaching experience and beliefs cited earlier, we used multiple regression to partial out the effects of training and experience on teacher beliefs; the highly significant differences between preand posttransition teachers' beliefs about Trust $(t[3,148]=8.57 ; p<.0001)$, Control $(t[3,148]=-4.86 ; p<.0001)$, Autonomy $(t[3,148]=2.74 ; p<$ $.01)$, and Efficacy $(t[3,148]=5.38 ; p<.0001)$, remain. For pretransition teachers there were no significant correlations between teachers' experience and training in math and the five belief scales. For posttransition teachers there was a significant positive correlation between the number of years teaching math at this grade level and the belief that ability is stable $(r=.35 ; p$ $<.01$ ).

For the posttransition sample only, we asked teachers if they have elementary certification, secondary certification, or both. Using analysis of variance, type of certification is not related to the beliefs of these posttransition teachers, with the exception of control ideology (Control). Posttransition teachers with only elementary certification have a less controlling ideology than those with secondary certification or both certificates $(F[2,60]=5.86$; 
$p<.01)$. However, when the effects of teacher sex are partialled out, this association is no longer significant $(p<.08)$.

\section{DISCUSSION AND IMPLICATIONS}

When children move to the junior high school they come in contact with mathematics teachers who have different beliefs about controlling and trusting students, and about their personal efficacy than the teachers they had for math the previous year. Not only do the relations among these beliefs differ for pre- and posttransition teachers, but as predicted, posttransition teachers have less positive beliefs than do pretransition teachers. Although the link between these teacher belief systems and students' achievement-related beliefs and behaviors is yet to be firmly established, several lines of research suggest that these differences may contribute to a decline in students' achievement motivation and performance (Eccles and Midgley, in press).

But aside from the effect on students, it is important to think about the implications of these pre- and posttransition findings for teachers. If we believe, for example, it is important for teachers to feel efficacious, then we must take seriously the fact that a remarkable $15 \%$ of the variance on the personal efficacy scale is accounted for by being a pre- or posttransition teacher, despite the fact that the students being taught by these two groups of teachers are the same. Although student characteristics undoubtedly affect teachers' sense of efficacy, it is difficult to believe developmental changes in students over a one-year period are primarily responsible for the differences in pre- and posttransition teachers' beliefs. What else might be contributing to this difference? Are the people who choose to teach in junior high school inherently different from those who choose the elementary level? Are they trained differently? And do these differences influence their belief systems? We find no empirical evidence in the literature to support this suggestion. One of the main conclusions reached by Ashton and her colleagues is that teacher sense of efficacy is not a character trait, but rather is situation specific (e.g., Ashton, 1985, p. 166). Although researchers have consistently found a relation between control ideology and a few personality variables, such as dogmatism (Heinman, 1971; Keffe, 1969; Williams, 1972; Willower et al., 1973) and status obeisance (Helsel, 1971a), elementary and secondary teachers typically have quite similar dogmatism and status obeisance scores (Helsel, 1971a; Willower, 1969). There are certainly some difference in the training that elementary and secondary teachers receive. Although we find differences in the experience and training reported by preand posttransition teachers in this study, the highly significant effect of school level on teacher beliefs about control, trust, and personal efficacy remains 
when differences in training and experience are taken into account. For posttransition teachers, type of certification is unrelated to teacher beliefs with the exception of control ideology. Posttransition teachers with elementary certification only are less controlling than teachers with secondary certification or both certificates. However, male teachera re more controlling than female teachers and more male than female junior high school teachers have secondary certification. In fact, when sex of teacher is taken into account, the association between certification and beliefs about control is no longer significant.

Is the departmentalized organization of the junior high school responsible for the differences in teacher beliefs? Junior high school teachers, in comparison to elementary teachers, work with many more students for a much shorter period of time each day. Perhaps having to interact with and coordinate the activities of so many students elicits a more controlling and less trustful orientation, and reduces a teacher's sense of efficacy. In support of this suggestion, organizational structure has emerged as an important mediator of school transition effects in some studies (Hawkins and Berndt, 1985; Power, 1981). For example, Hawkins and Berndt (1985) found a more marked decline in self-concept among students moving into a traditional departmentalized junior high school than students moving into a school with interdisciplinary teams, multi-age classrooms, and an exploratory curriculum. Similarly, Ashton found that teachers in a departmentalized junior high school exhibited a somewhat lower sense of personal teaching efficacy than teachers in a less traditional junior high school; these differences, however, were not statistically significant (Ashton et al., 1983). In contrast, the presence or absence of departmentalization in the middle school was not associated with control idology in a study by Hedberg (1973). Further work needs to be undertaken to better understand the relation between the organization of both the middle school and junior high school and teacher beliefs about themselves and their students. ${ }^{8}$ If there is a relationship, the advantages and disadvantages of the traditional departmentalized system need to be debated.

We would like to suggest another influence on posttransition teachers' beliefs. It is likely that teacher beliefs are influenced by the cultural stereotypes in the broader society. There is evidence that early adolescence is viewed by society as a particularly difficult and unproductive stage of life (Holm-

${ }^{8}$ During the last 25 years many school districts have changed from junior high to middle schools. Although the middle school was originally conceived as a "philosophy and belief about children, their unique needs, who they are, and how they grow and learn" (DeVita et al., 1970, p. 25), in reality many middle schools are departmentalized and differ from junior high schools in name and grade organization only. 
beck and Hill, 1986; Lavigne, 1977; Offer et al., 1981). Teachers may be influenced by media coverage of a controversial theory of brain growth based on the work of Epstein (1978) that is cited as evidence of a deficit in cognitive processing during early adolescence. These societal views are not likely to engender feelings of efficacy or trust in those who work with early adolescents. Is there something about an institution that is exclusively for early adolescents that allows these stereotypes to flourish and become the dominant ethos?

A number of researchers have talked about the powerful effect of the shared beliefs of teachers in a school, or the school "ethos." The contention is that in some schools, particularly those with a high proportion of minority or lower class students, stereotypes flourish and teachers come to believe students are unlikely to make much academic progress and must be controlled (e.g., Edmonds, 1984; Leacock, 1969; Levy, 1970), and these beliefs, in turn, have been shown to influence both teacher behaviors and student outcomes (Brophy and Good, 1974; Brookover et al., 1979; Leacock, 1969). For example, in a study of city schools, learning to take orders and to be submissive was the stated goal for children in schools in low-income areas (Leacock, 1969). Similarly, teachers in low-socioeconomic status schools have consistently been found to believe more strongly in controlling and disciplining students than those in middle- or high-socioeconomic schools (Andrews, 1973; Barfield and Burlingame, 1974; Gossen, 1969; McBride, 1972).

The similarity between the beliefs of teachers in low socioeconomic schools and schools for early adolescents is provocative. In his description of a ghetto school, Levy (1970) discusses the "homogenization" of teacher values and describes the process by which teachers come to adopt the norms of their peers. What are the norms in schools for early adolescents? Are teachers in institutions for early adolescents socialized to believe they are dealing with an age group that is difficult to teach, not to be trusted, and in need of control and discipline? Are junior high school children another subset of students who are viewed by their teachers as less teachable and manageable than other students? It will be ironic if, in creating the junior high school system to meet the special needs of this unique age group, we have created an institution in which negative beliefs about early adolescents flourish, and both teachers and students are victims.

If we are to better understand the effect of the transition to junior high school on early adolescent development, it seems important to try to determine why there are significant differences in the belief systems of pre- and posttransition teachers, how these differences relate to the academic motivation and performance of their students, and what can be done to make the beliefs of junior high school teachers more positive and facilitative. It will also be important to assess the beliefs of teachers at other grade levels 
within the junior high school; in other school organizations that serve early adolescents, such as the middle school and the K-8 school; and in subject matter areas other than mathematics.

\section{ACKNOWLEDGMENTS}

The authors thank Lee Jussim and the members of the Achievement Research Laboratory at the Institute for Social Research for their comments on early drafts of this paper.

Anderson, J. G. (1968). Bureaucracy in Education. Johns Hopkins Press, Baltimore, MD. Andrews, B. J. (1973). Relationships between selected community variables and school atmosphere. Unpublished doctoral dissertation, Rutgers University.

Armor, D., Conry-Oseguera, P., Cox, M., King, N., McDonnell, L., Pascal, A., Pauly, E., and Zellman, G. (1976). Analysis of the school preferred reading program in selected Los Angeles minority schools. Report No. R-2007-LAUSD, The Rand Corporation, Santa Monica, CA: (ED 140432 .)

Ashton, P. (1985). Motivation and the teacher's sense of efficacy. In Ames, C., and Ames, R. (eds.), Research on Motivation in Education, Vol. 2: The Classroom Milieu. Academic Press, Orlando, FL.

Ashton, P. T., and Webb, R. B. (1986). Making a Difference: Teachers' Sense of Efficacy and Student Achievement. Longman, New York.

Ashton, P. T., and Webb, R. B. (1982). Teachers' sense of efficacy: Toward an ecological model. Paper presented at the annual meeting of the American Educational Research Association, New York.

Ashton, P. T., Olejnik, S., Crocker, L., and McAuliffe, M. (1982, March). Measurement problems in the study of teachers' sense of efficacy. Paper presented at the annual meeting of the American Educational Research Association, New York.

Ashton, P. T., Webb, R. B., and Doda, N. (1983). A Study of Teachers' Sense of Efficacy. Florida University, Gainesville, FL: (ED 231 833.)

Barfield, V., and Burlingame, M. (1974). The pupil control ideology of teachers in selected schools. J. Exp, Educ, 42: 6-11.

Beady, C. H., Jr., and Hansell, S. (1981). Teacher race and expectations for student achievement. Am. Educ. Res. J. 18: 191-206.

Berman, P., McLaughlin, M., Bass, G., Pauly, E., and Zellman, G. (1977). Federal programs supporting educational change, Vol. 7: Factors affecting implementation and continuation. Report No. R-1589/7-HEW, The Rand Corporation, Santa Monica, CA.

Bloom, B. S. (1978). New views of the learner: Implications for instruction and curriculum. Ed. Leader. 35: 563-576.

Blyth, D. A., Simmons, R. G., and Carlton-Ford, S. (1983). The adjustment of early adolescents to school transitions. J. Early Adoles. 3: 105-120.

Brenneman, O. N., Willower, D. J., and Lynch, P. D. (1975). Teacher self-acceptance, acceptance of others, and pupil control ideology. J. Exp. Educ. 44: 14-17.

Brookover, W., Beady, C., Flood, P., Schweitzer, J., and Wisenbaker, J. (1979). School Social Systems and Student Achievement: Schools Can Make a Difference. Praeger, New York.

Brooks, R. C. (1977). A study to establish behavioral and other correlates of the Pupil Control Ideology form at the junior and senior high school level. Dissert. Abst. Int. 38: $1762 \mathrm{~A}-1763 \mathrm{~A}$. 
Brophy, J., and Evertson, C. (1977). Learning from Teaching: A Developmental Perspective. Allyn and Bacon, Boston.

Brophy, J. E., and Good, T. (1974). Teacher behaviors and student learning in second and third grades. In Borich, G. D. (ed.), The Appraisal of Teaching: Concepts and Process. Addison-Wesley, MA.

Brown, R., and Gibson, S. (1982). Teachers' sense of efficacy: Changes due to experience. Summary of a presentation at the California Educational Research Association Conference, Sacramento, CA.

Budzik, J. M. (1971). The relationship between teachers' ideology of pupil control and their perception of administrative control style. Dissert. Abstr. Int. 32: 1212A.

Cooper, H. M., and Baron, R. M. (1977). Academic expectations and attributed responsibility as predictors of professional teachers' reinforcement behavior. J. Educ. Psychol. 69: 409-418.

deCharms, R. (1976). Enhancing Motivation: Change in the Classroom. Irvington, New York.

Deci, E. L., Schwartz, A. J., Sheinman, L., and Ryan, R. M. (1981). An instrument to assess adults' orientations toward control versus autonomy with children: Reflections on intrinsic motivation and perceived competence. J. Educ. Psychol. 73: 642-650.

DeVita, J. C., Pumerantz, P., and Wilklow, L. B. (1970). The Effective Middle School. Parker, West Nyack, NY.

Duncan, M. J., and Biddle, B. J. (1974). The Study of Teaching. Holt, Rinehart \& Winston, New York.

Dusek, J. (ed.). (1985). Teacher Expectancies. Erlbaum, Hillsdale, NJ.

Eccles, J., and Midgley, C. (in press). Stage/environment fit: Developmentally appropriate classrooms for early adolescents. In Ames, R. E., and Ames, C. (eds.), Research on Motivation in Education (Vol. 3). Academic Press, New York.

Eccles, J., and Wigfield, A. (1985). Teacher expectations and student motivation. In Dusek, J. (ed.), Teacher Expectancies. Erlbaum, Hillsdale, NJ.

Eccles, J., Midgley, C., and Adler, T. F. (1984). Grade-related changes in the school environment: Effects on achievement motivation. In Nicholls, J. G. (ed.), Advances in Motivation and Achievement. JAI Press, Greenwich, CT.

Edmonds, R. (1984). School effects and teacher effects. Social Policy 15, 37-39.

Epstein, H. T. (1978). Growth spurts during brain development: Implications for educational policy and practice. In Chall, J. S., and Mirsky, A. F. (eds.), Education and the Brain: The Seventy-Seventh Yearbook of the National Society for the Study of Education (Part II). University of Chicago Press, Chicago.

Feldlaufer, H., and Midgley, C. (1987, April). Student, teacher, and observer perceptions of the classroom environment before and after the transition to junior high school. Paper presented at the annual meeting of the American Educational Research Association, Washington, DC.

Finger, J. A., and Silverman, M. (1966). Changes in academic performance in the junior high school. Person. Guid. J. 45: 157-164.

Fuller, B., and Izu, J. A. (1986). Explaining school cohesion: What shapes the organizational beliefs of teachers? Am. J. Educ. 94: 501-535.

Gibson, S., and Dembo, M. H. (1984). Teacher efficacy: A construct validation. J. Educ. Psychol. 76: 569-582.

Glickman, C. D., and Tamashiro, R. T. (1982). A comparison of first-year, fifth-year, and former teachers on efficacy, ego development, and problem solving. Psychol. Schools 19: $558-562$

Good, T. L. (1981). Teacher expectations and student perceptions: A decade of research. Educ. Leader. 38: 415-422.

Gossen, H. A. (1969). An investigation of the relationship between socioeconomic status of elementary schools and pupil control ideology of teachers. Unpublished doctoral dissertation, Oklahoma State University.

Green, L., and Foster, D. (1986). Classroom intrinsic motivation: Effects of scholastic level, teacher orientation, and gender. J. Educ. Res. 80: 34-39.

Guskey, T. R. (1981a). Differences in teachers' perceptions of the causes of positive vs. negative student achievement outcomes. Paper presented at the annual meeting of the American Educational Research Association, Los Angeles, CA. 
Guskey, T. R. (1981b). Measurement of the responsibility teachers assume for academic successes and failures in the classroom. J. Teacher Educ. 32: 44-51.

Guskey, T. R. (1982). The effects of change in instructional effectiveness on the relationship of teacher expectations and student achievement. J. Educ. Res. 75: 345-348.

Guskey, T. R. (1986). Context variables that affect measures of teacher efficacy. Paper presented at the annual meeting of the American Educational Research Association, San Francisco, CA.

Hamil, P. A. (1971). An analysis of the observed change in the student-teachers' pupil control ideology as compared to the pupil control ideology of the cooperating teacher. Dissert. Abst. Int. 33: 646A.

Hawkins, J. A., and Berndt, T. J. (1985, April). Adjustment following the transition to junior high school. Paper presented at the biennial meeting of the Society for Research in Child Development, Toronto.

Hedberg, J. D. (1973). Pupil control ideology of middle school teachers and its relationship to student alienation and to selected organizational and teacher variables. Dissert. Abst. Int. 34: 1024A-1025A.

Heinman, R. J. (1971). Relationships among selected values, levels of dogmatism, and pupil control ideologies of high school principals. Dissert. Abstr. Int. 32: 5498A, 5499A.

Helsel, A. R. (1971a). Status obeisance and pupil control ideology. J. Educ. Admin. 9: 38-47.

Helsel, A. R. (1971b). Value orientation and pupil control ideology of public school educators. Educ. Admin. Quart. 7: 24-33.

Holmbeck, G. N., and Hill, J. P. (1986, March). Beliefs in storm and stress notions of adolescence: Prevalence and developmental antecedents. Paper presented at the biennial meeting of the Society for Research on Adolescence, Madison, WI.

Hoy, W. K. (1967). Organizational socialization: The student teacher and pupil control ideology. J. Educ. Res. 61: 153-155.

Hoy, W. K. (1968). The influence of experience on the beginning teacher. School Rev. 76: 312-323.

Hoy, W. K. (1969). Pupil control ideology and organizational socialization: A further examination of the influence of experience on the beginning teacher. School Rev. 77: 257-265.

Hoy, W. K. (1972). Dimensions of student alienation and pupil control orientations of high schools. Interchange 3: 38-52.

Hoy, W. K., and Kupersmith, W. J. (1984, April). The concept of trust: An empirical assessment. Paper presented at the annual meeting of the American Educational Research Association, New Orleans, LA.

Jones, T. E. (1969). The relationship between bureaucracy and the pupil control ideology of secondary school and teachers. Dissert. Abst. Int. 31: 3818A.

Jury, L. E., Willower, D. J., and DeLacy, W. J. (1975). Teacher self-actualization and pupil control ideology. Alberta J. Educ. Res. 21: 295-301.

Keffe, J. A. (1969). The relationship of the pupil control ideology of teachers to key personal and organizational variables. Unpublished doctoral dissertation.

Lavigne, J. V. (1977). The pediatric hospital staff's knowledge of normal adolescent development. J. Pediat. Psychol. 2: 98-100.

Lawler, E. E. (1976). Control systems in organizations. In Dunnette, M. D. (ed.), Handbook of Industrial and Organizational Psychology. Rand McNally, Chicago.

Leacock, E. B. (1969). Teaching and Learning in City Schools. Basic Books, New York.

Leppert, E., and Hoy, W. K. (1972). Teacher personality and pupil control ideology. J. Exp. Educat. 40: 57-59.

Levy, G. (1970). Ghetto School: Class Warfare in an Elementary School. Pegasus, New York.

Lipsitz, J. S. (1977). Growing Up Forgotten: A Review of Research and Programs Concerning Early Adolescence. Heath, Lexington, MA.

Lipsitz, J. S. (1980). The age group. In Johnson, M. (ed.), Toward Adolescence: Seventy-Ninth Yearbook of the National Society for the Study of Education, University of Chicago Press, Chicago.

Marshall, H. H., and Weinstein, R. S. (1984). Classroom factors affecting students' selfevaluations: An interactional model. Rev. Educ. Res. 54: 301-325.

McArthur, J. T. (1978). What does teaching do to teachers? Educ. Admin. Quart. 14: 89-103. 
McBride, A. P. (1972). A comparative study of a group of New Jersey middle schools and junior high schools in relation to their pupil control ideology and select pupil behaviors. Dissert. Abst. Int. 33: 1371A.

Medway, F., and Baron, R. (1977). Locus of control and tutor's instructional style as determinants of cross-age tutoring effectiveness. Contemp. Educ. Psychol. 2: 298-310.

Mergendoller, J. R. (1982, April). To facilitate or impede? The impact of selected organizational features of secondary schools on adolescent development. Paper presented at the annual meeting of the American Educational Research Association, New York.

Metz, M. H. (1978). Classrooms and Corridors: The Crisis of Authority in Desegregated Secondary Schools. University of California Press, Berkeley, CA.

Murray, H. B., and Staebler, B. K. (1974). Teacher's locus of control and student achievement gains. J. School Psychol. 12: 305-309.

Nottelmann, E. (1987). Competence and self-esteem during transition to adolescence. Develop. Psychol. 23: 441-450.

Oakes, J. (1981). Tracking policies and practices: School by school summaries. A Study of Schooling: Technical Report No. 25. University of California Graduate School of Education, Los Angeles, CA.

Offer, D., Ostrov, E., and Howard, K. I. (1981). The mental health professional's concept of the normal adolescent. Arch. Gen. Psychiatr. 38: 149-153.

Passe, J. (1984). The relationship between teacher morale, teacher perceived efficacy and student achievement. Paper presented at the annual meeting of the American Educational Research Association, New Orleans, LA.

Petersen, A., Ebata, A., and Graber, J. (1987, April). Responses to developmental and family changes in early adolescence. Paper presented at the annual meeting of the American Educational Research Association, Washington, DC.

Porter, L. W., and Lawler, E. E. (1965). Properties of organization structure in relation to job attitudes and job behavior. Psychol. Bull. 64: 23-51.

Power, C. (1981). Changes in students' attitudes toward science in the transition between Australian elementary and secondary schools. J. Res. Sci. Teaching, 18: 33-39.

Rafalides, M., and Hoy, W. K. (1971). Student sense of alienation and pupil control orientation of high schools. High School J. 55: 101-111.

Roberts, R. A., and Blankenship, J. W. (1970). The relationship between the change in pupil control ideology of student teachers and student teachers' perception of the cooperating teacher's pupil control ideology. J. Res. Sci. Teaching, 7: 315-320.

Rose, J. S., and Medway, F. J. (1981). Measurement of teachers' beliefs in their control over student outcomes. J. Educ. Res. 74: 185-190.

Rutter, M., Maughan, B., Mortimore, P., Ouston, J., and Smith, A. (1979). Fifteen Thousand Hours: Secondary Schools and Their Effects on Children. Harvard University Press, Cambridge, MA.

Selove, R. (1984). Relationships among teachers' expectations and school organizational variables. Paper presented at the American Psychological Association, Toronto, Ontario.

Showers, B. K. (1980). Self-efficacy as a predictor of teacher participation in school decision making. Dissert. Abst. Int. 41: 3496A.

Silberman, C. E. (1970). Crisis in the Classroom. Random House, New York.

Simmons, R. G., and Blyth, D. A. (1987). Moving into Adolescence: The Impact of Puberial Change and School Context. Aldine de Gruyler, Hawthorn, NY.

Simmons, R. G., Blyth, D. A., Van Cleave, E. F., and Bush, D. (1979). Entry into early adolescence: The impact of school structure, puberty, and early dating on self-esteem. Am. Sociol. Rev. 44: 948-967.

Sprintall, N. A. (1985). Early adolescents and opportunities for growth in the 1980s: Ships passing in the night, again. J. Early Adoles. 5: 533-547.

Trentham, L., Silvern, S., and Brogdon, R. (1985). Teacher efficacy and teacher competency ratings. Psychol. Schools 22: 343-352.

Waple, C. C. (1974). Relationship between existence of "ressentiment," students' perception of internal-external control, and pupil control ideology of certificated high school staff in selected Ohio public schools. Dissert. Abs. Int. 35: 1939-A. 
Ward, B. A. Mergendoller, J. R., and Tikunoff, W. J. (1982). Introduction to the Junior High School Transition Study. J. Early Adoles. 4: 311-317.

Williams, M. (1972). The pupil control idology of public school personnel and its relationship to specified personal and situational variables. Dissert. Abst. Int. 33: 3237A-3238A.

Willower, D. J. (1969). Schools as organizations: Some illustrated strategies for educational research and practice. J. Educ. Admin. 7: 110-126.

Willower, D. J. (1977). Schools and pupil control. In Erickson, D. A. (ed.), Educational Organization and Administration. McCutcheon, Berkeley, CA.

Willower, D. J., and Jones, R. G. (1967). Control in an educational organization. In Rath, J. D., Pancella, J., and VanNess, J. (eds.), Studying Teaching, Prentice-Hall, Englewood Cliffs, NJ.

Willower, D. J., and Landis, C. A. (1970). Pupil control ideology and professional orientation of school faculty. J. Second. Educ. 45: 118-123.

Willower, D. J., and Lawrence, J. D. (1979). Teachers' perceptions of student threat to teacher status and teacher pupil control ideology. Psychol. Schools 16: 586-590.

Willower, D. J., Eidell, T. L., and Hoy, W. K. (1973). The school and pupil control ideology. Pennsylvania State Studies Monograph. No. 24, Pennsylvania State University Press, University Park, PA.

Yuskiewicz, V. D., and Willower, D. J. (1973). Perceived pupil control ideology consensus and teacher job satisfaction. Urban Educ. 8: 231-238. 